\title{
Pengaruh Transparansi, LKPD dan PAD Terhadap Kinerja Pemerintah Daerah
}

\author{
Pardomuan Robinson Sihombing ${ }^{1}$, Ade Marsinta Arsani ${ }^{2}$ \\ ${ }^{1}$ Badan Pusat Statistik, robinson @bps.go.id \\ ${ }^{2}$ Badan Pusat Statistik, ade.marsinta@bps.go.id
}

\begin{abstract}
ABSTRAK
Kinerja pemerintah daerah mencerminkan ketercapaian sasaran dan tujuan yang telah ditetapkan oleh instansi berdasarkan visi dan misi yang telah disusun sebelumnya. Terdapat banyak faktor yang mempengaruhi kinerja pemerintah daerah, antara lain transparansi, akuntabilitas laporan keuangan, serta pendapatan daerah. Penelitian ini bertujuan untuk mengetahui pengaruh Transparansi, Laporan Keuangan Pemerintah Daerah (LKPD) dan Pendapatan Asli Daerah (PAD) terhadap Kinerja Pemerintah Daerah (Pemda). Pengujian dilakukan pada 295 Kabupaten dan Kota di Indonesia dengan menggunakan data sekunder berupa data LKPD, Opini Audit Badan Pemeriksa Keuangan (BPK) dan Laporan Realisasi Anggaran (LRA). Hasil penelitian menunjukkan bahwa baik secara simultan maupun secara parsial transparansi, LKPD dan PAD berpengaruh signifikan positif terhadap kinerja pemda. Hal ini berarti peningkatan transparansi, LKPD dan PAD akan meningkatkan kinerja pemda. Implikasi penelitian ini, dapat digunakan sebagai dasar dalam pengambilan keputusan mengenai pengelolaan pendapatan daerah, terutama dalam transparansi anggaran yang dapat meningkatkan kepercayaan publik terhadap Pemda. Penyusunan laporan keuangan yang baik dan pengelolaan PAD untuk belanja modal diharapkan dapat menyentuh langsung kepada pelayanan publik sehingga meningkatkan kinerja Pemda.
\end{abstract}

Kata kunci: transparansi, PAD, LKPD, audit, kinerja

\begin{abstract}
Local governments' performance reflects the achievement of the goals and objectives set by the agency based on the vision and mission that has been prepared. Many factors affect the performance of local governments, including transparency, accountability of financial statements, and regional income. This study aims to determine the effect of transparency, local government financial report and local own revenue to the performance of local government. The test was conducted in 295 municipalities in Indonesia using secondary data in the form of Local Government Accountability data, Audit Opinions of the BPK and the Budget Realization Report. The results found that both simultaneously and partially Transparency, Regional Government Financial Reports and the Original Revenue of the District had a significant positive effect on the performance of the local government. It means that the increase in transparency, regional government financial reports and local revenue will improve the performance of local government. The implications of this research can be used as a basis for making decisions regarding the management of local revenue, especially in budget transparency, as it can increase public confidence in local governments. The well-prepared financial reports and the management of local revenue for capital expenditure have a direct implication on public services, so that improve local government performance.
\end{abstract}

Keywords : transparency, local revenue, audit, performance

Naskah diterima: 26-08-2020, direvisi: 19-06-2020, diterbitkan: 01-09-2020

ISSN: 2355-0295, e-ISSN: 2549-8932

http://ejournal.bsi.ac.id/ejurnal/index.php/ecodemica 


\section{PENDAHULUAN}

Keberhasilan Pemerintah Daerah (Pemda) dalam mengelola keungannya, dapat diukur dari kinerja keuangannya. Seiring kebijakan pasca reformasi, pemerintah pusat memberikan kebijakan otonomi pada suatu daerah dalam mengelolah keuangan. Keuangan daerah perlu dikelola secara mandiri oleh Pemda, tujuannya agar proses pembangunan yang dilakukan dapat diselesaikan tanpa harus menunggu bantuan pendanaan yang bersumber dari Pusat oleh sebab itu pengukuran kinerja keuangan penting untuk dilakukan.

Salah satu hal yang dapat dilakukan untuk mewujudkan pertanggungjawaban pemerintah terhadap warganya dengan menggunakan prinsip transparansi (keterbukaan). Menurut Astuti (2013), melalui transparansi penyelenggaraan pemerintahan, masyarakat diberikan kesempatan untuk mengetahui kebijakan yang akan dan telah diambil oleh pemerintah. Selain itu, masyarakat dapat memberikan masukan terhadap kebijakan yang telah diambil oleh pemerintah.

Pendapatan Asli Daerah (PAD) merupakan salah pendapatan daerah selain DAU, DAK dan dana perimbangan. PAD dijadikan salah satu pi;ar kemandirian daerah karena bersumber dari kegiatan ekonominya sendiri. Kemampuan suatu daerah dalam menggali PAD, akan mempengaruhi perkembangan dan pembangunan daerah tersebut, sehingga apabila kontribusi PAD meningkat terhadap APBD, maka akan semakin kecil ketergantungan terhadap bantuan pemerintah pusat. Menurut Bastian (2012), PAD dapat dipergunakan sesuai dengan kehendak dan inisiatif Pemda untuk kelancaran penyelenggaraan urusan Daerah, sehingga mampu meningkatkan kinerja Pemda.

Penggunaan PAD dan keuangan pemerintah daerah setiap tahun diukur kinerjanya melalui predikat yang diberikan oleh Badan Pusat Keuangan (BPK). Kinerja keuangan ini dapat digunakan sebagai tolak ukur keberhasilan daerah otonom dalam menyelenggarakan otonomi daerah. laporan kinerja keuangan inidapat dilihat pertanggung jawaban pemda kepada masyarakat yang telah memberikan kontribusi melalui pajak dalam membangun daerahnya. Sehingag laporan keuangan pemerintah daerah dapat dijadikan tolak ukur kinerja pemerintah daerah.

\section{KAJIAN LITERATUR}

Coryanata (2007), menyatakan konsep transparansi dibangun atas dasar arus informasi yang bebas, seluruh proses pemerintahan, lembaga-lembaga dan informasi perlu diakses oleh pihak-pihak yang berkepentingan, dan informasi yang tersedia perlu memadai agar dapat dimengerti dan dipantau. Anggaran yang disusun oleh pihak eksekutif dikatakan transparansi jika memenuhi beberapa Kriteria, yaitu melakukan pengumuman kebijakan anggaran, dokumen anggaran dan mudah diakses, laporan pertanggung jawaban yang tepat waktu, akomodasi suara atau usulan rakyat, serta sistem pemberian informasi pada public.

Menurut MenPAN (2007), kinerja Pemda merupakan gambaran mengenai tingkat pencapaian sasaran ataupun tujuan instansi pemerintah sebagai penjabaran dari visi, misi dan strategi instansi pemerintah yang mengindikasikan tingkat keberhasilan dan kegagalan pelaksanaan kegiatan-kegiatan sesuai dengan program dan kebijakan yang ditetapkan. Sumarsono (2010), mengungkapkan indikator pengukuran kinerja yang baik mempunyai karakteristik relevant, unambiguous, cost-effective, dan simple, serta berfungsi sebagai sinyal yang menunjukkan bahwa terdapat masalah yang memerlukan tindakan manajemen dan investigasi lebih lanjut.

Pengelolaan keuangan yang baik dapat mengindikasikan kinerja keuangan yang baik. Pengolahan keuangan ini lebih dikenal dengan istilah akuntabilitas. Secara harfiah akuntabilitas (accountability) umumnya dapat diartikan sebagai pertanggungjawaban, namun penerjemahan secara sederhana ini dapat mengaburkan arti kata accountability itu sendiri bila dikaitkan dengan pengertian akuntansi dan manajemen. Di Indonesia penilaian akuntabilitas ini dilakukan oleh lembaga Badan Pemeriksa Keuangan yang 
akan memberikan opini terkait data keuangan suatu instansi atau pemerintah daerah.

Menurut Agustina (2013), menyatakan tujuan dari otonomi daerah dan desentraliasi fiskal menurut UU Nomor 32 tahun 2004 adalah untuk meningkatkan kemandirian. Hal ini akan mengurangi ketergantungan fiskal Pemda terhadap Pemerintah Pusat. Salah satu intrumen kemandirian dengan menggunakan PAD yang dimiliki oleh daerah untuk meningkatkan kemajuan dan kesejahteraan masyarakatnya.

\section{METODE PENELITIAN}

Variabel dependen penelitian ini adalah kriteria kinerja Pemda yang terdiri dari nilai A, B,BB, C dan CC. Sedangkan variabel independennya adalah transparansi yang merupakan indeks keterbukaan, LKPP yang merupakan hasil audit BPK berupa status MMP, WDP dan WDP, serta variabel pendapatan asli daerah (PAD).

Metode analisis yang dipakai dalam model adalah analisis regresi linier berganda dengan metode estimasi OLS (Ordinary Least Square) atau Metode Kuadrat Terkecil untuk data cross section. Sampel yang digunakan sebanyak 295 sampel Kabupaten dan Kota yang memiliki isian lengkap. Metode OLS merupakan metode analisis regresi yang paling kuat dan populer (Gujarati, 2006).

Berikut ini adalah spesifikasi model yang dipergunakan:

KinerjaPemd $a=\beta 0+\beta 1$ tranparansi $+\beta 2 L K P D+\beta 3 P A D+\varepsilon t$ di mana:

$\beta 0=$ intercept, kontanta

$\beta 1, \beta 2 \beta 3=$ koefisien regresi/ slope, besarnya pengaruh variabel indpenden terhadap dependen

$\varepsilon$

$$
=\text { error term }
$$

kinerja $\mathrm{Pemda}=$ berubah status capaiakn kinerja, nilainya A hingga $\mathrm{C}$

transparansi $=$ nilai keterbukaan/ transparansi Pemda

LKPD=merupakan capaian audit keuangan yang dikeluarkan oleh BPK

$\mathrm{PAD}=$ pendapatan asli daerah

Berdasarkan penelitian terdahulu dan teoriteori yang telah dijelaskan di atas, maka dapat dibangun hipotesis sebagai berikut: :
1. $\frac{\text { Kinerja }}{\text { transparansi }}>0$, terdapat pengaruh positif antara variabel transparansi terhadap kinerja, asumsi cateris paribus.

2. $\frac{\text { Kinerja }}{\text { LKPD }}>0$, terdapat pengaruh positif antara variabel LKPD terhadap kinerja, asumsi cateris paribus.

3. $\frac{\text { Kinerja }}{P A D}<0$, terdapat pengaruh positif antara variabel PAD terhadap kinerja, asumsi cateris paribus.

\section{PEMBAHASAN}

\section{Analisis Deskriptif}

Dari 295 kabupaten/kota pada umumnya kualitas kinerja PEMDA bernilai B sebanyak 127 Kabupaten dan Kota (43 persen) dan ada 9 kabupaten kota yang sudah mendapatkan kinerja A. Hal ini mengindikasikan bahwa kinerja pemerintah kabupaten kota sangat bervariasi, dari yang kinerjanya sangat baik hingga buruk.

Tabel 1 Kinerja Pemerintah Daerah

\begin{tabular}{|r|r|r|r|}
\hline Kode & Kinerja & Jumlah & Persentase \\
\hline 1,00 & $\mathrm{C}$ & 39 & 13,2 \\
\hline 2,00 & $\mathrm{CC}$ & 89 & 30,2 \\
\hline 3,00 & $\mathrm{~B}$ & 127 & 43,1 \\
\hline 4,00 & $\mathrm{BB}$ & 31 & 10,5 \\
\hline 5,00 & $\mathrm{~A}$ & 9 & 3,1 \\
\hline Total & & 295 & 100,0 \\
\hline
\end{tabular}

Dari 295 kabupaten/kota pada umumnya LKPP pemda sudah WTP sebanyak 259 kabupaten/kota (87,8 persen) dan ada 2 kabupaten kota yang masih MMP.

Tabel 2 Predikat Laporan Kinerja Pemerintah Daerah

\begin{tabular}{|l|r|r|r|}
\hline Kode & LKPP & \multicolumn{1}{|c|}{ Jumlah } & \multicolumn{1}{c|}{ Persentase } \\
\hline 1,00 & MMP & 2 &, 7 \\
\hline 3,00 & WDP & 34 & 11,5 \\
\hline 4,00 & WTP & 259 & 87,8 \\
\hline Total & & 295 & 100,0 \\
\hline
\end{tabular}

\section{Analisis Inferensia}

Sebelum dimodelkan menggunakan regresi linier berganda, terlebih dahulu dilakukan ujia asumsi klasik. 


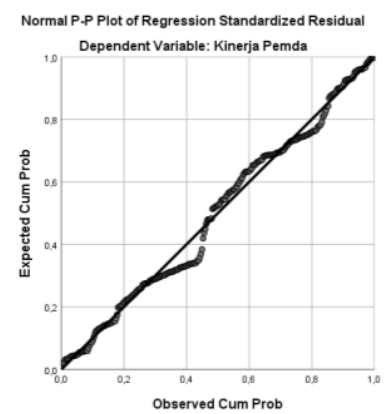

Gambar 1 Diagram P-P Plot
Dalam penelitian ini menggunakan dua jenis uji yaitu pengujian dengan menggunakan grafik Scatter Plot dan uji glejzer yang meregresikan seluruh variabel independen dengan nilai absolut residual dari model. Jika dilihat dari pola redisual yang tidak membentuk pola dan nilai probability value $=0,053>$ alpa $=0,05$ maka dapat dikatakan bahwa model yang digunakan sudah bebas dari asumsi heterokedastisitas.

Tabel 4 ANOVA Heteroskedastisitas

Dalam penelitian ini menggunakan dua jenis uji yaitu pengujian dengan menggunakan grafik P-P Plot dan uji Kolmogorv Smirnov. Jika dilihat dari pola redisual yang berada pada garis $\mathrm{y}=\mathrm{x}(450)$ dan nilai $\mathrm{z}$ stat $=0,158<$ $\mathrm{z}$ tabel $=1,96$ serta nilai probability value $=0,20$ $>$ alpa=0,05 maka dapat dikatakan bahwa data yang digunakan sudah mengikuti pola distribusi normal.

Tabel 3 Uji Kolmogorov-Smirnov

\begin{tabular}{|l|l|r|}
\hline \multicolumn{2}{|c|}{} & abse \\
\hline N & 295 \\
\hline Normal Parameters ${ }^{\mathrm{a}, \mathrm{b}}$ & Mean &, 6998 \\
\cline { 2 - 3 } & $\begin{array}{l}\text { Std. } \\
\text { Deviation }\end{array}$ &, 47979 \\
\hline $\begin{array}{l}\text { Most Extreme } \\
\text { Differences }\end{array}$ & Absolute &, 158 \\
\cline { 2 - 3 } & Positive &, 158 \\
\cline { 2 - 2 } & Negative &,- 081 \\
\hline Test Statistic &, 158 \\
\hline Asymp. Sig. (2-tailed) &, $200^{\mathrm{c}}$ \\
\hline \multicolumn{2}{|l|}{ a. Test distribution is Normal. } \\
\hline \multicolumn{2}{|l|}{ b. Calculated from data. } \\
\hline \multicolumn{2}{|l|}{ c. Lilliefors Significance Correction. } \\
\hline
\end{tabular}

Pengujian asumsi selanjutnya adalah heteroskedastisitas.

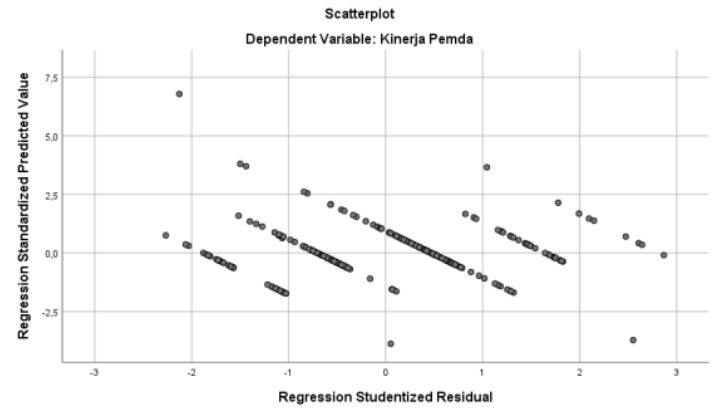

Gambar 2 Scatter Plot Heteroskedastisitas

\begin{tabular}{|c|c|c|c|c|c|c|}
\hline \multicolumn{7}{|c|}{ ANOVA $^{\mathrm{a}}$} \\
\hline \multicolumn{2}{|c|}{ Model } & Sum of & $\mathrm{df}$ & Mea & $\mathrm{F}$ & Sig. \\
\hline \multirow[t]{3}{*}{1} & Regression & 1,757 & 3 & 58 & 2,58 & 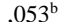 \\
\hline & Residual & 65,922 & 291 & ,23 & & \\
\hline & Total & 67,680 & 294 & & & \\
\hline \multicolumn{7}{|c|}{ a. Dependent Variable: abse } \\
\hline \multicolumn{7}{|c|}{ b. Predictors: (Constant), PAD , Kualitas LKPD, Transparan } \\
\hline
\end{tabular}

Asumsi selanjutnya adalah multikolinieritas.

Tabel 5 VIF

\begin{tabular}{|r|c|}
\hline \multicolumn{2}{|c|}{ Collinearity Statistics } \\
\hline Tolerance & VIF \\
\hline, 946 & 1,057 \\
\hline, 970 & 1,031 \\
\hline, 962 & 1,040 \\
\hline
\end{tabular}

Dalam penelitian ini menggunakan nilai VIF (Varian Inflation Factor) untuk menguji multikolinieritas. Semua nilai VIF lebih kecil 10, maka dapat dikatakan bahwa model yang digunakan sudah bebas dari masalah multikolinearitas.

Setelah semua uji asumsi klasik terpenuhi, maka interpretasi terhadap model dapat dilakukan.

\begin{tabular}{|l|r|r|r|r|}
\hline \multirow{2}{*}{} & \multicolumn{2}{|c|}{$\begin{array}{c}\text { Unstandardized } \\
\text { Coefficients }\end{array}$} & $\mathrm{t}$ & Sig. \\
\cline { 2 - 4 } & $\mathrm{B}$ & $\begin{array}{c}\text { Std. } \\
\text { Error }\end{array}$ & & \\
\hline (Constant) &, 426 &, 486 &, 876 &, 382 \\
\hline Transparansi &, 051 &, 013 & 3,860 &, 000 \\
\hline $\begin{array}{l}\text { Kualitas } \\
\text { LKPD }\end{array}$ &, 460 &, 127 & 3,623 &, 000 \\
\hline PAD &, 551 &, 108 & 5,102 &, 000 \\
\hline R & \multicolumn{5}{|l}{, 446} \\
\hline R-square & & &, 199 \\
\hline
\end{tabular}




\begin{tabular}{|l|l|}
\hline $\begin{array}{l}\text { Adj. R- } \\
\text { square }\end{array}$ &, 191 \\
\hline
\end{tabular}

Dari hasil di atas nilai korelasi sebesar 0,446 mengatakan ada hubungan positif antara seluruh variabel independen dengan variabel dependen. Nilai adjusted $r$ square atau biasanya disbeut koefisien determinasi sebesar 0,191 artinya seluruh variabel independen (PAD, Kualitas LKPD dan transparansi) mampu menjelaskan variabel dependen (kinerja pemerintah) sebesar 19,1 persen. Hal ini menunjukkan model kurang fit karena nilainya kurang dari 0,5 . Sehingga diperlukan variabel independen lainnya yang mempengaruihi kinerja Pemda.

Persamaan regresi yang didapat dari hasil di atas adalah

Kiner ja pe mda $=0,426+0,051$ Transparansi + Adapun interpretasi dari persamaan tersebut adalah:

Koefisien Transparansi berpengaruh signifikan positif terhadap kinerja pemda dengan koefisien sebesar 0,051 dengan nilai t stat $=3,860>\mathrm{t} 291 ; 0.05=1,96$ dan nilai probabilita $=0,000<$ alpa $=0,05$. Hal ini berarti setiap kenaikan 1 poin transparansi akan menaikan kinerja pemda 0,051 dengan asumsi variabel variabel lain konstan. Hal yang menyebabkan transparansi berpengaruh terhadap kinerja pemerintah daerah adalah karena transparansi yang dilakukan melalui SKPD dapat mengungkapkan informasi keuangan dan non-keuangan kepada publik melalui media secara tepat waktu, memadai,jelas, akurat dan dapat diperbandingkan serta mudah diakses oleh pihak-pihak berkepentingan (stakeholders) sesuai dengan haknya. Hal ini sejalan dengan penelitian Novatiani (2019) meneliti bagaimana pengaruh transparansi dan akuntabilitas terhadap kinerja instansi pemerintah pada SKPD Kabupaten Bandung Barat. Hasil pengujian hipotesis menunjukkan bahwa transparansi dan akuntabilitas berpengaruh terhadap kinerja instansi pemerintah baik secara parsial maupun secara simultan. Hal ini didasarkan apabila aparatur pemerintah menerapkan transparansi dengan baik maka baik secara langsung atau tidak langsung akan menampilkan kinerja terbaiknya dalam menjalankan tugas dan tanggungjawabnya.

Koefisien Kualitas LKPD berpengaruh signifikan positif terhadap kinerja pemda dengan koefisien sebesar 0,460 dengan nilai t stat $=3,623>t_{291 ; 0.05}=1,96$ dan nilai probabilita $=0,000<$ alpa $=0,05$. Hal ini berarti setiap kenaikan 1 poin kualitas LKPD akan menaikan kinerja pemda 0,460 dengan asumsi variabel variabel lain konstan. Hal ini senada dengan penelitian Auditya dan Lismawati (2013) yang menyatakan akuntabilitas pengelolaan keuangan berpengaruh positif dan signifikan terhadap kinerja pemerintah daerah. Dengan demikian semakin tinggi dan akuntabel pengelolaan keuangan daerah di setiap SKPD maka akan dapat meningkatkan kinerja pemerintah.

Koefisien PAD berpengaruh signifikan

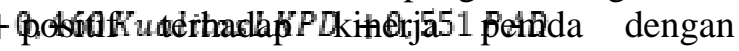
koefisien sebesar 0,551 dengan nilai $t$ stat $=5,102>\mathrm{t} 291 ; 0.05=1,96$ dan nilai probabilita $=0,000<$ alpa $=0,05$. Hal ini berarti setiap kenaikan $1 \%$ PAD akan menaikan kinerja pemda 0,551 dengan asumsi variabel variabel lain konstan. Hal ini dikarenakan PAD merupakan cerminan kemandirian daerah. PAD yang meningkat dari tahun ketahun dan mampu membiayai jalannya Pemerintahan daerah diharapkan mampu meningkatkan kemandirian daerah. Hal ini senada dengan penelitian Wenny (2012), yang menemukan secara simultan PAD berpengaruh terhadap kinerja keuangan daerah, sehingga semakin tinggi PAD yang dikumpulkan Pemerintah Daerah maka kinerja keuangannya semakin baik.

\section{PENUTUP}

Adapun kesimpulan dalam penelitian ini adalah: bahwa variabel independen (PAD, Kualitas LKPD dan transparansi) berpengaruh secara linier dan signifikan secara bersamasama terhadap variabel dependen (kinerja pemerintah). Kenaikan transparansi anggaran, LKPD dan PAD akan meningkatkan kinerja Pemda. 


\section{REFERENSI}

Agustina,O.2013.

Analisis

Kinerja

Pengelolaan Keuangan Daerah dan

Tingkat Kemandirian Daerah di Era

Otonomi Daerah : Studi Kasus Kota

Malang Tahun 2007-2011. (Jurnal Ilmiah

Mahasiswa FEB Universitas Brawijaya:

Volume 1 Nomor 2, Februari 2013,

https://jimfeb.ub.ac.id/index.php/jimfeb/ar ticle/view/394)

Astuti, M, Ratih.2013. Pengaruh Akuntabilitas ,Transparansi dan Fungsi Pemeriksaan Intern Terhadap Kinerja Pemerintah Daerah (Studi Kasus Pada Dinas Pendapatan Pengelolaan Keuangan dan Aset Daerah (DPPKAD) Kabupaten Grobogan). (Skripsi Fakultas Ekonomi dan Bisnis Universitas Muhammadiyah Surakarta 2013.

http://eprints.ums.ac.id/26967/9/NASKAH PPUBLIKASI.pdf)

Auditya, Lucy dan Lismawati, Husaini. 2013. Analisis Pengaruh Akuntabilitas dan Transparansi Keuangan Daerah Terhadap Kinerja Pemerintah Daerah (Jurnal Fairness Volume 3 Nomor 1, Maret 2013, http://repository.unib.ac.id/6940/1/Artikel 1.pdf)

Bastian, I. 2012. Akuntansi Sektor Publik Suatu Pengantar. Jakarta: Erlangga.

Coryanata, Isma. 2007. Akuntabilitas, Partisipasi Masyarakat, dan Transparansi Kebijakan Publik Sebagai Pemoderating Hubungan Pengetahuan Dewan Tentang Anggaran dan Pengawasan Keuangan Daerah (APBD). (Jurnal Akuntansi dan Investasi Volume 12 Nomor 2, Juli 2012, https://journal.umy.ac.id/index.php/ai/arti cle/view/678/830)

Gujarati, Damodar N. 2006. Ekonometrika Dasar. Jakarta : Erlangga

Novatiani, et.al.2019. Pengaruh Transparansi dan Akuntabilitas Terhadap Kinerja Instansi Pemerintah. (Jurnal Manajemen dan Bisnis : Volume 10 Nomor 1, Maret 2019,

https://ejournal.upi.edu/index.php/mdb/art icle/view/15983)

Sumarsono, S.2010. Manajemen Keuangan Pemerintahan. Edisi Pertama. Cetakan Pertama. Yogyakarta: Graha Ilmu.
Wenny, C.D. 2012. Analisis Pengaruh Pendapatan Asli Daerah (PAD) terhadap Kinerja Keuangan pada Pemerintah Kabupaten dan Kota di Provinsi Sumatera Selatan (Jurnal Ilmiah STIE MDP Volume 2 Nomor 1, Februari 2012, http://eprints.mdp.ac.id/676/)

\section{BIODATA PENULIS}

Pardomuan Robinson Sihombing adalah Statistisi di Badan Pusat Statistik.

Penulis menyelesaikan pendidikan sarjana terapan di Sekolah Tinggi Ilmu Statistik dan telah menyelesaikan pendidikan magister di jurusan Magister Statistika Terapan, Universitas Padjadjaran.

Ade Marsinta Arsani adalah Statistisi di Badan Pusat Statistik. Penulis menyelesaikan pendidikan sarjana terapan di Sekolah Tinggi Ilmu Statistik dan sedang menyelesaikan pendidikan magister secara double degree di Magister Ekonomi Terapan Universitas Padjadjaran dan MPMA Program di Rikkyo University - Jepang 